\title{
Neuronal cell differentiation of mesenchymal stem cells originating from canine amniotic fluid
}

\author{
Eun Young Kim $\cdot$ Kyung-Bon Lee $\cdot$ Jung Yu $\cdot$ \\ Ji Hye Lee · Keun Jung Kim • Kil-Woo Han • \\ Kang-Sun Park $\cdot$ Dong-Soo Lee $\cdot$ Min Kyu Kim
}

Received: 11 August 2013/Accepted: 25 September 2013/Published online: 29 October 2013

(C) The Author(s) 2013. This article is published with open access at Springerlink.com

\begin{abstract}
The amniotic fluid contains mesenchymal stem cells (MSCs) and can be readily available for tissue engineering. Regenerative treatments such as tissue engineering, cell therapy, and transplantation show potential in clinical trials of degenerative diseases. Disease presentation and clinical responses in the Canis familiaris not only are physiologically similar to human compared with other traditional mammalian models but is also a suitable model for human diseases. The aim of this study was to investigate whether canine amniotic-fluid-derived mesenchymal stem cells (cAF-MSCs) can differentiate into neural precursor cells in vitro when exposed to neural induction reagent. During neural differentiation, cAF-MSCs progressively acquire neuron-like morphology. Messenger RNA (mRNA) expression levels of neural-specific genes, such as NEFL, NSE, and TUBB3 ( $\beta$ III-tubulin) dramatically increased in the differentiated cAF-MSCs after induction. In addition, protein expression levels of nestin, $\beta$ III-tubulin, and tyrosine hydroxylase remarkably increased in differentiated cAF-MSCs. This study demonstrates that cAF-MSCs have great potential for neural
\end{abstract}

Eun Young Kim and Kyung-Bon Lee contributed equally to this work.

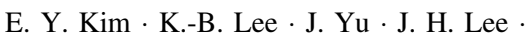

K. J. Kim · K.-W. Han · K.-S. Park · M. K. Kim ( $₫)$

Laboratory of Animal Reproduction and Physiology, Department of Animal Science and Biotechnology, College of Agriculture Life Science, Chungnam National University, Daejeon 305-764, Republic of Korea

e-mail: kminkyu@cnu.ac.kr

D.-S. Lee

Department of Regeneration and Advanced Medical Sciences, Graduate School of Medicine, Gifu University, Gifu 501-1193, Japan precursor differentiation in vitro. Therefore, amniotic fluid may be a suitable alternative source of stem cells and can be applied to cell therapy in neurodegenerative diseases.

Keywords Amniotic fluids - Mesenchymal stem cells - Degenerative diseases $\cdot$ Canine $\cdot$ Neural precursor $\cdot$ Neurodegenerative diseases

\section{Introduction}

Prior to new medical treatments being approved for regenerative medicine, clinical trials in animal models are essential [1-3]. A number of researchers demonstrate that Canis familiaris is a suitable model for human diseases [4, 5]. First, humans and dogs share the environmental life pattern. Physiologically, disease presentation and clinical symptom of the dog are much more similar to those of the human compared with other traditional animal models, and half of the canine diseases also belong to the group of human diseases [5]. In the gene database of inherited disorders and traits in $>135$ animal species, the dog has the most important potential as an animal model for human disease. Also, genomically, the genetic bases of disease susceptibility, morphological variation, and behavioral traits in dogs are significantly related with humans [6, 7]. Therefore, $C$. familiaris could be a promising animal model for human regenerative medicine.

Mesenchymal stem cells (MSCs), generally known as adult stem cells, were first isolated from postnatal bone marrow [8], and its presence was identified in most mammalian tissues. Principal sources of MSCs are bone marrow, umbilical-cord blood, olfactory bulb, amniotic fluid (AF), and Wharton's jelly $[9,10]$. As MSCs derived from AF (AF-MSCs) have the potential for self-renewal and 
multipotency, they are also defined as stem cells. AF-MSCs are easily isolated and demonstrate multiple differentiation abilities [11-15]. AF-MSCs can be differentiated into chondrogenic, adipogenic, osteogenic, myogenic, endothelial, and neurogenic pathways, as with other MSC sources [14, 16-22]. However, the difference between embryonic stem cell and other MSC sources is that AF stem cells have anti-inflammatory, low immunogenic characteristics; display nontumorigenicity; and there are few ethical issues surrounding their clinical application [23-25]. For those reasons, AF cells have advantages as materials for regenerative medicine.

Stem-cell-mediated therapy is a potential clinical treatment for degenerative diseases. One type of degenerative disease, neurological disorders, has limited treatment because the condition of the nervous system cannot be completely recovered after damage [26, 27]. To improve treatment of neurodegenerative disorders, MSC-mediated cell therapy and transplantation has been studied during the past two decades [28]. Many researchers demonstrate that stem cells can be differentiated into neural precursor cells $[18-20,29,30]$, and their use in clinical treatments has been tried.

The aim of tis study was to investigate whether MSCs originating from canine AF (cAF-MSCs) can differentiate into neural precursor cells by using an identical neural induction reagent. We also examined whether differentiated neural cAF-MSCs have the characteristics of dopaminergic cells that secret the dopamine neurotransmitter to prevent Parkinson's disease.

\section{Materials and methods}

Unless otherwise stated, all chemicals used in this study were purchased from Sigma-Aldrich Chemical Co. (USA). The protocol for this research was approved by the Research Ethics Committee of Chungnam National University.

Isolation and culture of canine amniotic-fluid-derived cells

Canine AF cells were characterized to MSCs by the method described previously [31]. Briefly, canine AF was collected from cesarean section by centesis under ultrasonographic guidance. The collected AF was centrifuged at 3,000 rpm for $10 \mathrm{~min}$, and the pellet was washed twice with phosphate-buffered saline (PBS, Gibco). Isolated AF cells were seeded into a $60-\mathrm{mm}$ culture dish containing low-glucose Dulbecco's modified Eagle medium (LDMEM) supplemented with $10 \%$ fetal bovine serum (FBS, Gibco), $5 \mathrm{ng} / \mathrm{ml}$ fibroblast growth factor (FGF),
$10 \mathrm{ng} / \mathrm{ml}$ epidermal growth factor (EGF), and $0.1 \%$ penicillin-streptomycin $(500 \mathrm{U} / \mathrm{ml}$ penicillin $-5 \mathrm{mg} / \mathrm{ml}$ streptomycin, P4458) at $39{ }^{\circ} \mathrm{C}, 5 \%$ carbon dioxide $\left(\mathrm{CO}_{2}\right)$ in air for 4-5 days.

Neural precursor differentiation of cAF-MSCs

For preneural differentiation, cAF-MSCs were cultured in L-DMEM supplemented with $10 \%$ FBS, $1 \times$ N2-supplement (Gibco), $10 \mathrm{ng} / \mathrm{ml} \mathrm{FGF,} 10 \mathrm{ng} / \mathrm{ml}$ EGF, and $0.1 \%$ penicillin-streptomycin. Two days after cultivation of preneural differentiation, the preinduction media was removed and cultured in L-DMEM supplemented with $0.5 \%$ FBS, 1x N2 supplement, 1 mM N6.2'-0-dibutyryl cyclic adenosine monophosphate (db-cAMP), $200 \mu \mathrm{M}$ butylated hydroxyanisole (BHA), and $0.1 \%$ penicillinstreptomycin at $39^{\circ} \mathrm{C}, 5 \% \mathrm{CO}_{2}$ in air for 5 days.

Morphological analysis

To clearly observe cell phenotype, cAF-MSCs were washed in PBS and stained using Diff-Quik kit (Sysmax Corporation, Japan), as recommended by the manufacturer's instructions. Briefly, cells were fixed by Diff-Quik fixative solution and stained by Diff-Quik solution I and II. The stained cells were observed using fluorescence microscope (TE2000-U, Nikon, Japan).

\section{RT-PCR analysis}

Total RNA (tRNA) was extracted using RNA extract kit (MACHEREY-NAGEL, Germany), as recommended by the manufacturer's instructions. RNA samples $(1 \mu \mathrm{g}$ tRNA) were primed with oligo dT primer to synthesize complementary DNA (cDNA) using iScript reverse transcriptase (Bio-Rad, USA). Real-time polymerase chain reaction (RT-PCR) reaction cycle consisted of a 3-min denaturation at $94{ }^{\circ} \mathrm{C}$, followed by 34 cycles at $94{ }^{\circ} \mathrm{C}$ for $30 \mathrm{~s}, 60{ }^{\circ} \mathrm{C}$ for $30 \mathrm{~s}$, and $72{ }^{\circ} \mathrm{C}$ for $30 \mathrm{~s}$. A final extension was completed at $72{ }^{\circ} \mathrm{C}$ for $5 \mathrm{~min}$, and RT-PCR reactions were modified to 35 cycles with primer annealing at 58-60 ${ }^{\circ} \mathrm{C}$. RT-PCR-specific amplification of target genes was confirmed by DNA sequencing. Results were evaluated by Image $\mathbf{J}$ (National Institute of Health, USA) and normalized to $\beta$ II-microglobulin ( $\beta-\mathrm{MG})$. Primers are listed in Table 1.

Immunocytochemistry analysis

Cells were rinsed three times in PBS and fixed with $4 \%$ paraformaldehyde (4 g paraformaldehyde in $100 \mathrm{ml}$ PBS) for $15 \mathrm{~min}$, followed by permeabilization with $0.1 \%$ Triton- $X$ 100 in PBS for $20 \mathrm{~min}$. Cells were then blocked and 
Table 1 Real-time polymerase chain reaction (RT-PCR) primer sequences for canine-neural-specific genes

\begin{tabular}{|c|c|c|c|c|}
\hline Gene & Ref sequence & Primer sequence $\left(5^{\prime}-3^{\prime}\right)$ & Annealing temperature $\left({ }^{\circ} \mathrm{C}\right)$ & Size (bp) \\
\hline$N E F L$ & NC_006607 & $\begin{array}{l}\text { Forward GAAGAAGCTGCCAAGGAAGA } \\
\text { Reverse GTTGACCTGATTTCGGGAGA }\end{array}$ & 58 & 202 \\
\hline GFAP & NC_006591 & $\begin{array}{l}\text { Forward ACCTGGCCAGTTATCGACAG } \\
\text { Reverse TCTTAGGGCTGCTGTGAGGT }\end{array}$ & 58 & 206 \\
\hline$N S E$ & NC_006609 & $\begin{array}{l}\text { Forward GAGAACAGTGAAGCCTTGGA } \\
\text { Reverse ACCAATCTGGTTGACCTTGA }\end{array}$ & 60 & 298 \\
\hline TUBB3 & NC_006587 & $\begin{array}{l}\text { Forward GCACACTGCTCATCAACAAG } \\
\text { Reverse TCTTGCTCTCCTTCATGGAC }\end{array}$ & 60 & 227 \\
\hline$B 2 M$ & NC_006612 & $\begin{array}{l}\text { Forward TCTACATTGGGCACTGTGTCAC } \\
\text { Reverse TGAAGAGTTCAGGTCTGACCAAG }\end{array}$ & 58 & 136 \\
\hline
\end{tabular}

incubated in rabbit anti-nestin antibody (Abcam, MA, USA) diluted 1:200, rabbit anti- $\beta$ III-tubulin antibody (Abcam) diluted 1:200, and rabbit anti-tyrosine hydroxylase (TH) antibody (Abcam) diluted 1:1000 in PBS containing $3 \%$ bovine serum albumin (BSA) overnight. Cells were washed three times again in PBS containing $1 \%$ Tween-20 and incubated with secondary immunoglobulin (Ig)G rabbit antibody (Abcam) diluted 1:200 in blocking solution for $40 \mathrm{~min}$ before final washing. The neuronal protein markers were detected under a confocal laser-scanning microscope (LSM5 live configuration Vario Two VRGB), processed with electronics and computer module (Real Time control system), and standard software (system configuration, ReUse function, acquisition, Z-function multitracking, presentation, image operation, fast-focusing system, etc.). At least ten fields of view from three to five independent experiments were used to count nestin, $\beta$ III-tubulin, and TH-positive cells: 4'0.6-Diamidino-2-phenylindole (DAPI, Life Technologies, CA, USA), which has a high affinity specifically for DNA, was used for nuclear staining to count total cell number.

Fluorescent-activated cell-sorter (FACS) analysis

Cells were harvested from the culture dish, centrifuged, resuspended in PBS, and fixed with $4 \%$ paraformaldehyde and permeabilized with $0.1 \%$ Triton-X 100. Neuronal cell markers were detected by anti-rabbit nestin antibody, $\beta$ tubulin III antibody, and TH antibody, followed by fluorescein-isothiocyanate-conjugated secondary antibody (Abcam) diluted 1:100. Concentrations of nestin, $\beta$-tubulin III, and $\mathrm{TH}$ antibody were described, as above. Results were analyzed using the fluorescent-activated cell-sorter (FACScan) instrument operating with CELLQuest software (Bencton Dickinson, USA).
Statistical analysis

Statistical data are presented as mean \pm standard error of the mean (SEM). Significant differences among samples were determined using the JMP 10 statistics program (SAS Institute, Inc., Cary, NC, USA). Comparisons for each pair or all pairs were analyzed using Student's $t$ test or TukeyKramer honestly significant difference test. Values of $P<0.05$ were considered to be significantly different.

\section{Result}

Morphological changes on differentiation of $\mathrm{cAF}$ MSCs into neural precursor cell

In our previous report, we noted that cAF-MSCs can be differentiated into adipocytes, osteocytes, and chondrocytes [31]. Moreover, according to FACS and immunocytometry, cAF-MSCs express mesenchymal markers. In this study, we used confirmed cAF-MSCs to estimate the capacity of differentiation into neuronal precursor cells. cAF-MSCs were induced for 5 days and morphological change was confirmed. cAF-MSCs were prepared in basic culture medium containing $10 \%$ FBS prior to culture (Fig. 1a, b). cAF-MSCs were first cultured for 2 days in predifferentiation medium with N2 supplementation (Fig. 1c) and for 3 days in final-differentiation medium (Fig. 1d). After preinduction, cAF-MSCs began to change morphologically into a spindle shape. Following final neural induction, cAF-MSCs progressively acquired long process extension and neuron-like morphology with a dendritic shape. 
Fig. 1 Morphological appearance of neural differentiated canine amniotic fluid mesenchymal stem cells (cAF-MSCs). a Before differentiation, cAF-MSCs showed fibroblast-like-shaped cells. b Undifferentiated cAFMSCs stained with Diff-Quick. c Spindle shape appeared in cAF-MSCs 2 days after induction of neural differentiation. $\mathbf{d}$ By the end of neuronal precursor

differentiation, cAF-MSCs were stained with Diff-Quick solution and could the progressively acquire neuron-like morphology, a large nucleus, and long processes
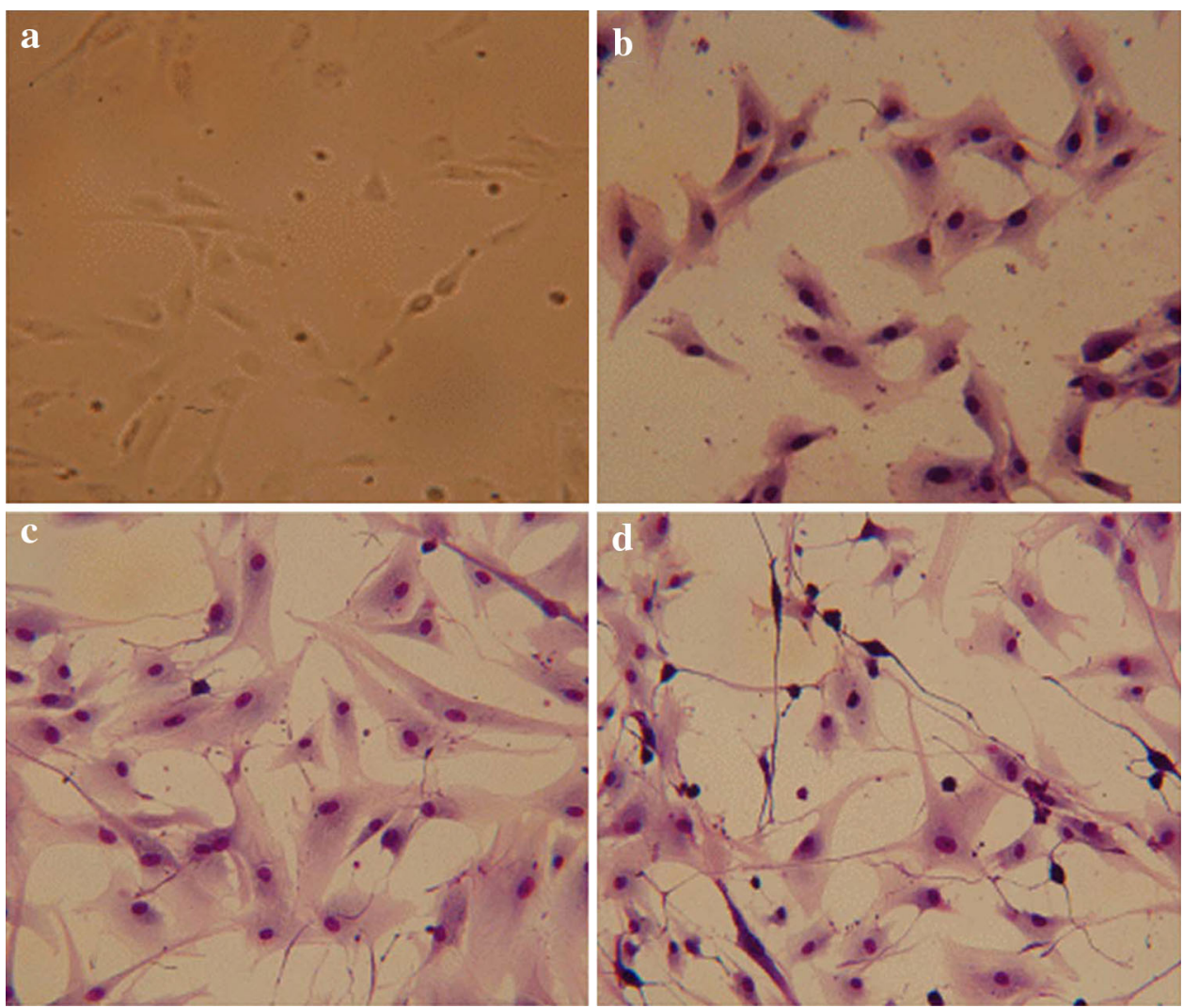

Expression levels of mRNA of neural specific genes on neural cell differentiation

To determine whether cAF-MSCs were induced into neural precursor cells, we tested expression levels of mRNA. RTPCR results indicated the expression of neural-specific genes, such as NEFL, NSE, TUBB3, and the astrocyte-specific gene, $G F A P$, in neuronal cAF-MSCs before (undifferentiation) and after (differentiation) neural induction. Canine brain tissue was used as a positive control. These genes showed little detectable expression levels of mRNA in the neuronal undifferentiated cAF-MSCs but were significantly increased after induction of neural differentiation (Fig. 2a). Expression levels of NEFL, GFAP, and TUBB3 mRNA were much higher in brain tissue. To quantify expression levels of mRNA of each gene, RT-PCR bands were calculated by Image J. Expression level of NEFL, TUBB3, and NSE was significantly increased after neural differentiation, even though GFAP was not significantly increased (Fig. 2b). Results showed very similar expression pattern between differentiated cAF-MSCs and mature neural cells.

Expression levels of neural-specific proteins on neuralcell differentiation

Neural-specific protein was analyzed in neuronal undifferentiated and differentiated cAF-MSCs by immunocytochemistry. Protein levels of neuronal-specific markers, such as nestin, $\beta I I I-t u b u l i n$, and the dopamine neuronal-specific marker, $\mathrm{TH}$, were not expressed in neuronal undifferentiated cAF-MSCs (Fig. 3a). However, protein levels of these markers were dramatically expressed in neuronal differentiated cAF-MSCs, even though TH was not strongly changed in immunocytochemical staining pattern compared with the expression level of undifferentiated cells (Fig. 3b). Interestingly, expression levels of nestin and $\beta \mathrm{III}-$ tubulin protein were higher than $\mathrm{TH}$ in differentiated cAF-MSCs. This result demonstrates that nestin, $\beta$ IIItubulin, and TH were only expressed in the cytoplasm and not in nuclei. Furthermore, differentiated neuronal cells can be differentiated to dopamine-related neuronal cells. This indicates that neuronal-specific peptide and protein, as well as dopamine neuronal-specific marker $\mathrm{TH}$, were expressed in differentiated cAFMSCs.

Expression levels of nestin, $\beta$ III-tubulin, and $\mathrm{TH}$ in differentiated cAF-MSCs were also confirmed after neural differentiation by FACS analysis (Fig. 4). The neuronaldifferentiated cAF-MSCs have a greatly increased expression of nestin (32\%), $\beta$ III-tubulin (70\%), and TH (43\%) compared with controls (Table 2). After neural differentiation, neural-cell-specific proteins were estimated by FACS. 
Fig. 2 Expression of neuronand astrocyte-specific markers. a NEFL, NSE, TUBB3, and $G F A P$ were confirmed by realtime polymerase chain reaction (RT-PCR). $\beta$ II microglobulin $[\beta-\mathrm{MG}(B 2 M)]$ and brain tissue were used as a housekeeping gene and positive control, respectively. b The intensity of messenger RNA (mRNA) expression levels of each gene was quantified and normalized to $\beta-\mathrm{MG}$ $\mathbf{a}$ Undifferentiation Differentiation Brain

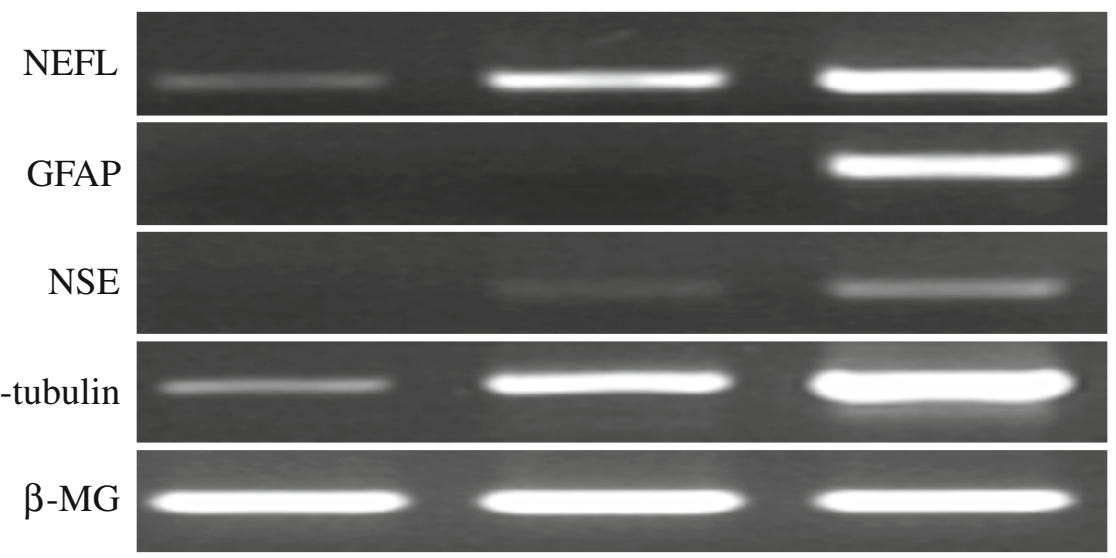

b

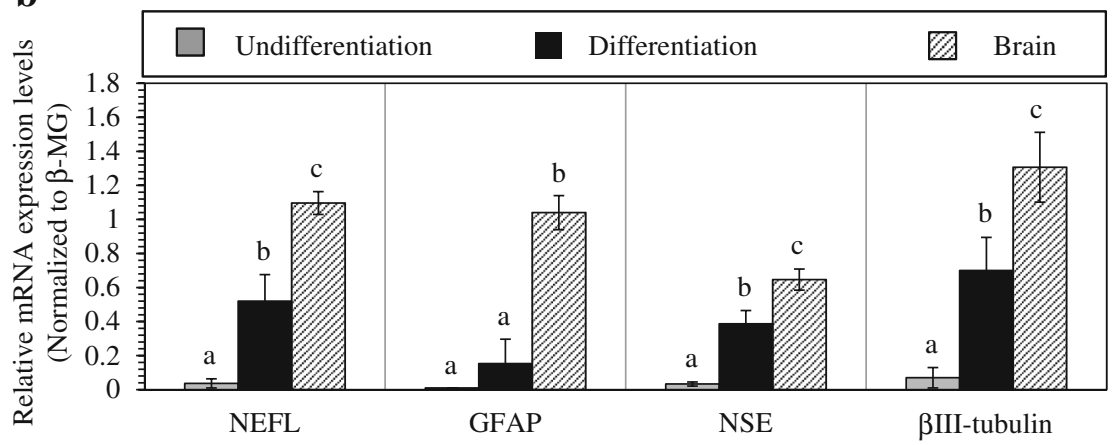

\section{Discussion}

In this study, we aimed to investigate whether MSCs originating from cAF-MSC can differentiate into neural precursor cells by identical neural induction reagent. By using N2 supplementation as a neural growth factor, this study was performed in two steps of induction protocol. The first step was preinduction with serum, basic growth factors, and N2 supplementation; the second step was induction with db-cAMP, BHA, and N2 supplementation. This two-step protocol is expected to reduce environmental damage to cells following a change of medium supplementation during induction of cell differentiation.

The intracellular cAMP level plays an important role in the differentiation [12], increasing intracellular cAMP levels, which activates the protein kinase A (PKA) signaling pathway, finally affecting initiate neural differentiation [32]. Previous studies attempted to differentiate neural precursor cells using various reagents, such as db-cAMP [12, 32, 33], neural growth factor [34], brain-derived neural factor [12, 34], 3-isobutyl-1-methylxanthine [12, 32], retinoic acid [12, 32], sonic hedgehog homolog [12, 35], forskolin [36] and 2-mercaptoethanol ( $\beta$-ME) [37].
The cAF-MSCs have proved their ability to differentiate into neural cells, and in our study, these cells possess the property of dopaminergic neurons. The cAF-MSCs differentiated into neuronal precursor and dopaminergic neurons, with this characteristic being identified though morphology, RT-PCR, immunocytochemistry, and FACS analysis. Dopamine, the catecholamine neurotransmitter, is an important indicator in Parkinson's diseases. Parkinson's disease is a progressively neurodegenerative disorder, caused mainly by degenerating dopamine neurons in the nigrostriatal pathway [38]. Therefore, replacement therapy using dopamine neurons could be a potentially successful treatment for patients with Parkinson's disease [39, 40]. TH is involved in the essential role of dopamine neuron development and is expressed from the hypothalamus, midbrain, brain stem, and olfactory bulb in the central nervous system (CNS). All catecholamine neuron cells, including dopamine neurons, highly express the $T H$ gene, which synthesizes catechol as a rate-limiting enzyme [12, 33]. The TH enzyme is also expressed in the amnion [41]. It suggested that amnion-derived stem cells, including AFMSCs, have the potential to be differentiated into dopaminergic neurons. Undifferentiated AF-MSCs weakly 
a

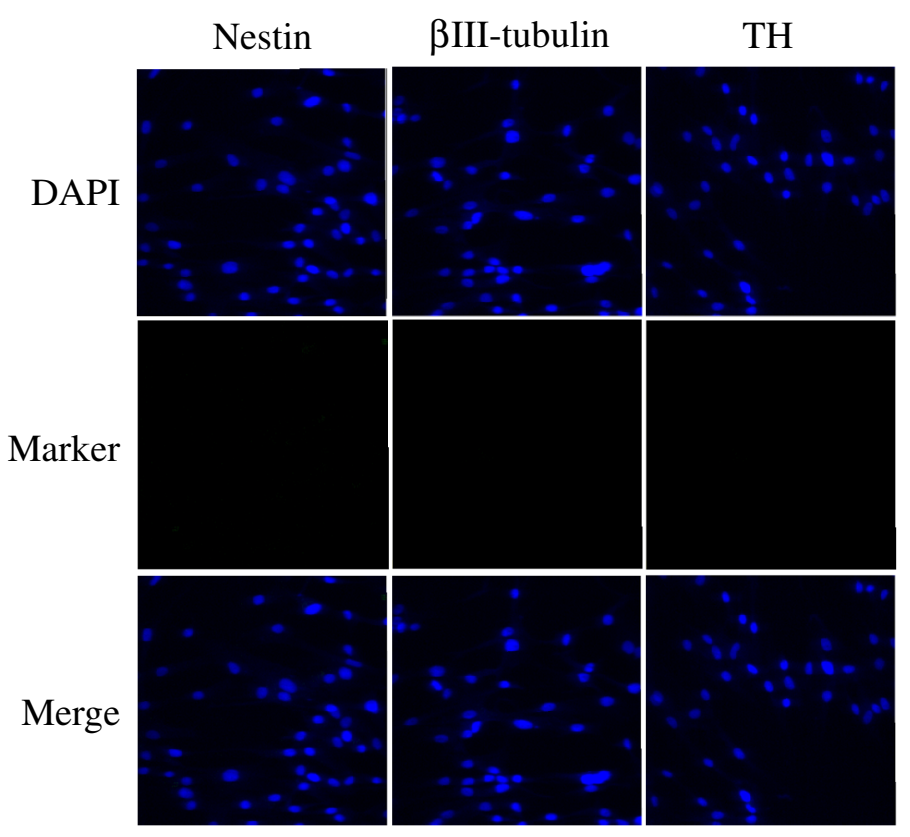

b

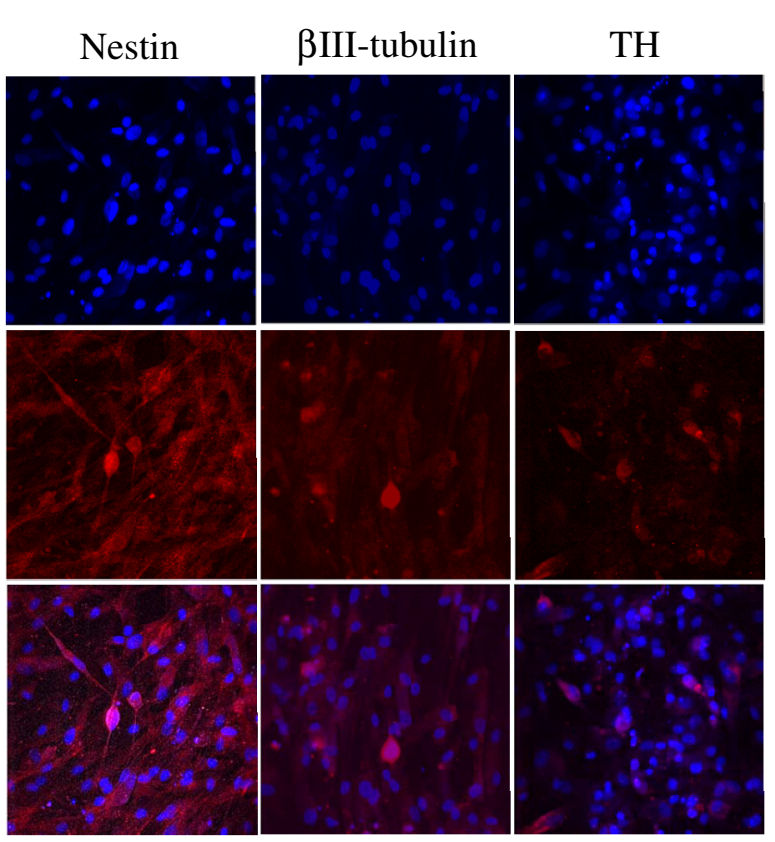

Fig. 3 Immunocytochemistry analysis for expression of neuronalcell-specific markers, such as nestin, BIII-tubulin, and dopamine neuronal-specific marker, tyrosine hydroxylase (TH). Immunocytochemistry was performed in canine amniotic fluid mesenchymal stem cells (cAF-MSCs), which were $\mathbf{a}$ undifferentiated and $\mathbf{b}$ differentiated. All neuronal-specific markers were detected in the cytoplasm of differentiated cells, and the nucleus WAS stained by $4^{\prime} 0.6$ Diamidino-2-phenylindole (DAPI). Magnification $=\times 100$
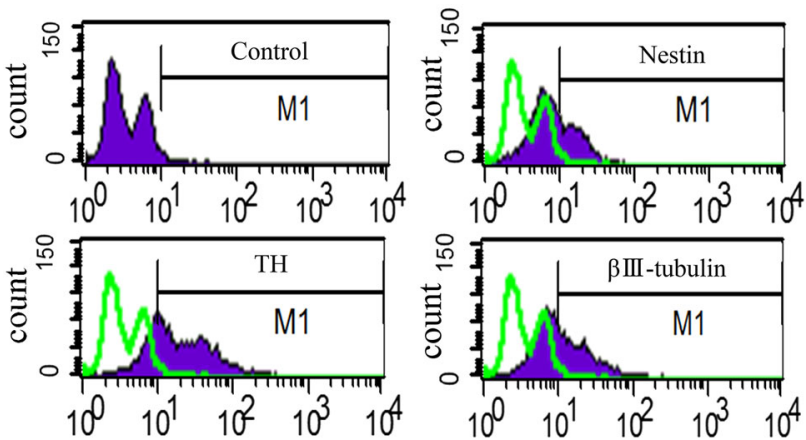

Fig. 4 Analysis of expression of neural-specific makers on differentiated neuronal canine amniotic fluid mesenchymal stem cells (cAFMSCs). Induced neural cAF-MSCs were collected, and III-tubulin, nestin, and tyrosine hydroxylase (TH) expression on their surfaces was measured by flow cytometry. cAF-MSCs: green-filled histograms represent staining with isotype-matched antibody

Table 2 Fluorescent-activated cell-sorter (FACS) analysis for expressed proportion of neuronal-cell and dopamine neuronal-cellspecific markers, such as $\beta$ III-tubulin, nestin, and tyrosine hydroxylase $(\mathrm{TH})$. The value of each expression level was evaluated after induction

\begin{tabular}{lllll}
\hline & Control & $\beta$ III-tubulin & Nestin & TH \\
\hline Expression (\%) & 1.2 & 69.7 & 32.22 & 43.04 \\
\hline
\end{tabular}

express some neuronal lineage markers, such as neuron, ganglia, catecholamine, dopamine, and neurotrophic factors $[23,42,43]$. These results mean that AF is ready to use as a potential source for the induction of neuronal cells and functional dopaminergic neurons.

The astrocyte, one of three major cell type of the CNS, plays an important role as a supporting neuronal cell. In neuronal and brain injury; however, astrocytes active proliferation rate and changes to the form of reactive gliosis [44]. Pathologically, these astrocytic changes contributed to progression of neuronal degeneration and inflammation, causing neuron degeneration disease [45]. Therefore, inflammatory reaction, such as the occurrence of macrophages and microglia, is related to treatment of neuronal degenerative diseases [46-48]. Analysis using mRNA shows that expression of neuronal-specific genes on neuronal-cell differentiation and GFAP expression level was not significantly increased. Therapeutically, low GFAP expression in undifferentiated and differentiated $\mathrm{cAF}$ MSCs is considered an advantage to this potential source of cell transplantation therapy.

This study demonstrates that cAF-MSCs have the ability to effectively differentiate into neural precursor cells and that $\mathrm{CAF}-\mathrm{MSC}$ s can be induced into dopamine neuron-like cells with db-cAMP and BHA treatment. Morphologically, after neural induction treatment, $\mathrm{cAF}$ - 
MSCs with a fibroblast-like shape changed to neural-like cells, with long processes, growth cone, dendritic processes, and neuron-network-like structures, as noted in the previous studies [18, 23]. By analyzing protein expression using immunocytochemistry, we corroborated the differentiation potential of cAF-MSCs. These results clearly show that cAF-MSCs could be differentiated into functional neuron precursor cells, in contrast with previous studies [1, 32, 34]. FACS analysis also shows that neural-induced cAF-MSCs indicate the considerable differentiation potential of nestin $(32.22 \%)$, BIII-tubulin (69.74\%), and TH (43.04\%).

In conclusion, cAF-MSCs were successfully differentiated into neuronal precursor and dopaminergic neurons at the same time by one neural induction method, with distinction of another method for dopaminergic induction. This study supports the potential capacity of cAF-MSCs for clinical treatment of neuronal precursor-cell transplantation.

Acknowledgments This work was supported by grant of the Cooperative Research Program for Agriculture Science and Technology Development (Project No. PJ009333) Rural Development Administration, Republic of Korea, and a grant (110056-3) from the Korea Institute of Planning and Evaluation for Technology (iPET), Ministry for Food, Agriculture, Forestry and Fisheries, Republic of Korea.

Open Access This article is distributed under the terms of the Creative Commons Attribution License which permits any use, distribution, and reproduction in any medium, provided the original author(s) and the source are credited.

\section{References}

1. Montzka K, Lassonczyk N, Tschöke B, Neuss S, Führmann T, Franzen R, Smeets R, Brook GA, Wöltje M. Neural differentiation potential of human bone marrow-derived mesenchymal stromal cells: misleading marker gene expression. BMC Neurosci. 2009;. doi:10.1186/1471-2202-10-16.

2. Seo MS, Jeong YH, Park JR, Park SB, Rho KH, Kim HS, Yu KR, Lee SH, Jung JW, Lee YS, Kang KS. Isolation and characterization of canine umbilical cord blood-derived mesenchymal stem cells. J Vet Sci. 2009;10:181-7.

3. Sago K, Tamahara S, Tomihari M, Matsuki N, Asahara Y, Takei A, Bonkobara M, Washizu T, Ono K. In vitro differentiation of canine celiac adipose tissue-derived stromal cells into neuronal cells. J Vet Med Sci. 2008;70:353-7.

4. Hayes B, Fagerlie SR, Ramakrishnan A, Baran S, Harkey M, Graf L, Bar M, Bendoraite A, Tewari M, Torok-Storb B. Derivation, characterization, and in vitro differentiation of canine embryonic stem cells. Stem Cells. 2008;26:465-73.

5. Schneider MR, Wolf E, Braun J, Kolb HJ, Adler H. Canine embryo-derived stem cells and models for human diseases. Hum Mol Genet. 2008;. doi:10.1093/hmg/ddn078.

6. Tsai KL, Clark LA, Murphy KE. Understanding hereditary diseases using the dog and human as companion model systems. Mamm Genome. 2007;18:444-51.

7. Lindblad-Toh K, Wade CM, Mikkelsen TS, Karlsson EK, Jaffe DB, Kamal M, Clamp M, Chang JL, Kulbokas EJ 3rd, Lander ES.
Genome sequence, comparative analysis and haplotype structure of the domestic dog. Nature. 2005;438:803-19.

8. Friedenstein AJ, Chailakhyan RK, Gerasimov UV. Bone marrow osteogenic stem cells: in vitro cultivation and transplantation in diffusion chambers. Cell Tissue Kinet. 1987;20:263-72.

9. Montesinos JJ, Flores-Figueroa E, Castillo-Medina S, FloresGuzmán P, Hernández-Estévez E, Fajardo-Orduña G, Orozco S, Mayani H. Human mesenchymal stromal cells from adult and neonatal sources: comparative analysis of their morphology, immunophenotype, differentiation patterns and neural protein expression. Cytotherapy. 2009;11:163-76.

10. Paniushin OV, Domaratskaia EI, Starostin VI. Mesenchymal stem cells: sources, phenotype, and differentiation potential. lzv Akad Nauk Ser Biol. 2006;(1):6-25.

11. Chen L, He DM, Zhang Y. The differentiation of human placenta-derived mesenchymal stem cells into dopaminergic cells in vitro. Cell Mol Biol Lett. 2009;14:528-36.

12. Barzilay R, Kan I, Ben-Zur T, Bulvik S, Melamed E, Offen D. Induction of human mesenchymal stem cells into dopamineproducing cells with different differentiation protocols. Stem Cells Dev. 2008;17:547-54.

13. De Coppi P, Bartsch G Jr, Siddiqui MM, Xu T, Santos CC, Perin L, Mostoslavsky G, Serre AC, Snyder EY, Yoo JJ, Furth ME, Soker S, Atala A. Isolation of amniotic stem cell lines with potential for therapy. Nat Biotechnol. 2007;25:100-6.

14. Carraro G, Perin L, Sedrakyan S, Giuliani S, Tiozzo C, Lee J, Turcatel G, De Langhe SP, Driscoll B, Bellusci S, Minoo P, Atala A, De Filippo RE, Warburton D. Human amniotic fluid stem cells can integrate and differentiate into epithelial lung lineages. Stem Cells. 2008;26:2902-11.

15. Fauza D. Amniotic fluid and placental stem cells. Best Pract Res Clin Obstet Gynaecol. 2004;18:877-91.

16. Mareschi K, Rustichelli D, Comunanza V, De Fazio R, Cravero C, Morterra G, Martinoglio B, Medico E, Carbone E, Benedetto C, Fagioli F. Multipotent mesenchymal stem cells from amniotic fluid originate neural precursors with functional voltage-gated sodium channels. Cytotherapy. 2009;11:534-47.

17. Takashima $\mathrm{S}$, Ise $\mathrm{H}$, Zhao $\mathrm{P}$, Akaike $\mathrm{T}$, Nikaido $\mathrm{T}$. Human amniotic epithelial cells possess hepatocyte-like characteristics and functions. Cell Struct Funct. 2004;29:73-84.

18. Tamagawa $\mathrm{T}$, Ishiwata I, Ishikawa $\mathrm{H}$, Nakamura $\mathrm{Y}$. Induced in vitro differentiation of neural-like cells from human amnionderived fibroblast-like cells. Hum Cell. 2008;21:38-45.

19. Lim JH, Byeon YE, Ryu HH, Jeong YH, Lee YW, Kim WH, Kang KS, Kweon OK. Transplantation of canine umbilical cord blood-derived mesenchymal stem cells in experimentally induced spinal cord injured dogs. J Vet Sci. 2007;8:275-82.

20. Tropel P, Platet N, Platel JC, Noël D, Albrieux M, Benabid AL, Berger F. Functional neuronal differentiation of bone marrowderived mesenchymal stem cells. Stem Cells. 2006;24:2868-76.

21. Zhao P, Ise H, Hongo M, Ota M, Konishi I, Nikaido T. Human amniotic mesenchymal cells have some characteristics of cardiomyocytes. Transplantation. 2005;79:528-35.

22. Wei JP, Zhang TS, Kawa S, Aizawa T, Ota M, Akaike T. Human amnion-isolated cells normalize blood glucose in streptozotocininduced diabetic mice. Cell Transplant. 2003;12:545-52.

23. Pfeiffer S, McLaughlin D. In vitro differentiation of human amniotic fluid-derived cells: augmentation towards a neuronal dopaminergic phenotype. Cell Biol Int. 2010;34:959-67.

24. Portmann-Lanz CB, Schoeberlein A, Portmann R, Mohr S, Rollini P, Sager R, Surbek DV. Turning placenta into brain: placental mesenchymal stem cells differentiate into neurons and oligodendrocytes. Am J Obstet Gynecol. 2010;. doi:10.1016/j.ajog.2009.10.893.

25. Toda A, Okabe M, Yoshida T, Nikaido T. The potential of amniotic membrane/amnion-derived cells for regeneration of various tissues. J Pharmacol Sci. 2007;105:215-28. 
26. Esposito E, Genovese T, Caminiti R, Bramanti P, Meli R, Cuzzocrea S. Melatonin reduces stress-activated/mitogen-activated protein kinases in spinal cord injury. $J$ Pineal Res. 2009;46:79-86.

27. Ryu HH, Lim JH, Byeon YE, Park JR, Seo MS, Lee YW, Kim WH, Kang KS, Kweon OK. Functional recovery and neural differentiation after transplantation of allogenic adipose-derived stem cells in a canine model of acute spinal cord injury. J Vet Sci. 2009;10:273-84.

28. Pountos I, Corscadden D, Emery P, Giannoudis PV. Mesenchymal stem cell tissue engineering: techniques for isolation, expansion and application. Injury. 2007;38(Suppl 4):S23-33.

29. Krabbe C, Zimmer J, Meyer M. Neural transdifferentiation of mesenchymal stem cells: a critical review. APMIS. 2005;113: 831-44.

30. Sanchez-Ramos J, Song S, Cardozo-Pelaez F, Hazzi C, Stedeford T, Willing A, Freeman TB, Saporta S, Janssen W, Patel N, Cooper DR, Sanberg PR. Adult bone marrow stromal cells differentiate into neural cells in vitro. Exp Neurol. 2000;164: 247-56.

31. Choi SA, Choi HS, Kim KJ, Lee DS, Lee JH, Park JY, Kim EY, Li X, Oh HY, Lee DS, Kim MK. Isolation of canine mesenchymal stem cells from amniotic fluid and differentiation into hepatocyte-like cells. In Vitro Cell Dev Biol Anim. 2013;49:42-51.

32. Tio M, Tan KH, Lee W, Wang TT, Udolph G. Roles of dbcAMP, IBMX and RA in aspects of neural differentiation of cord blood derived mesenchymal-like stem cells. PLoS One. 2010;5(2):e9398. doi:10.1371/journal.pone.0009398.

33. Tremblay RG, Sikorska M, Sandhu JK, Lanthier P, RibeccoLutkiewicz M, Bani-Yaghoub M. Differentiation of mouse neuro 2A cells into dopamine neurons. J Neurosci Methods. 2009;186: 60-7.

34. Kamishina H, Cheeseman JA, Clemmons RM. Nestin-positive spheres derived from canine bone marrow stromal cells generate cells with early neuronal and glial phenotypic characteristics. In Vitro Cell Dev Biol Anim. 2008;44:140-4.

35. Trzaska KA, Kuzhikandathil EV, Rameshwar P. Specification of a dopaminergic phenotype from adult human mesenchymal stem cells. Stem Cells. 2007;25:2797-808.

36. Jang S, Cho HH, Cho YB, Park JS, Jeong HS. Functional neural differentiation of human adipose tissue-derived stem cells using bFGF and forskolin. BMC Cell Biol. 2010;. doi:10.1186/14712121-11-25.

37. Woodbury D, Schwarz EJ, Prockop DJ, Black IB. Adult rat and human bone marrow stromal cells differentiate into neurons. J Neurosci Res. 2000;61:364-70.

38. Foti R, Zucchelli S, Biagioli M, Roncaglia P, Vilotti S, Calligaris R, Krmac H, Girardini JE, Del Sal G, Gustincich S. Parkinson disease-associated DJ-1 is required for the expression of the glial cell line-derived neurotrophic factor receptor RET in human neuroblastoma cells. J Biol Chem. 2010;285:18565-74.

39. Li M, Zhang SZ, Guo YW, Cai YQ, Yan ZJ, Zou Z, Jiang XD, Ke YQ, He XY, Jin ZL, Lu GH, Su DQ. Human umbilical veinderived dopaminergic-like cell transplantation with nerve growth factor ameliorates motor dysfunction in a rat model of Parkinson's disease. Neurochem Res. 2010;35:1522-9.

40. Winner B, Desplats P, Hagl C, Klucken J, Aigner R, Ploetz S, Laemke J, Karl A, Aigner L, Masliah E, Buerger E, Winkler J. Dopamine receptor activation promotes adult neurogenesis in an acute Parkinson model. Exp Neurol. 2009;219:543-52.

41. Sakuragawa N, Kakinuma K, Kikuchi A, Okano H, Uchida S, Kamo I, Kobayashi M, Yokoyama Y. Human amnion mesenchyme cells express phenotypes of neuroglial progenitor cells. J Neurosci Res. 2004;78:208-14.

42. Kakishita K, Elwan MA, Nakao N, Itakura T, Sakuragawa N. Human amniotic epithelial cells produce dopamine and survive after implantation into the striatum of a rat model of Parkinson's disease: a potential source of donor for transplantation therapy. Exp Neurol. 2000;165:27-34.

43. Uchida S, Inanaga Y, Kobayashi M, Hurukawa S, Araie M, Sakuragawa N. Neurotrophic function of conditioned medium from human amniotic epithelial cells. J Neurosci Res. 2000; 62:585-90.

44. Amanda K, William H, Takeshi K, Julie A, Ashley P, Ronald B, Marie E. Analysis of targeted mutation in $D J-1$ on cellular function in primary astrocytes. Toxicol Lett. 2009;184:186-91.

45. Park SS, Byeon YE, Ryu HH, Kang BJ, Kim Y, Kim WH, Kang KS, Han HJ, Kweon OK. Comparison of canine umbilical cord blood-derived mesenchymal stem cell transplantation times: involvement of astrogliosis, inflammation, intracellular actin cytoskeleton pathways, and neurotrophin-3. Cell Transpl. 2011;20:1867-80.

46. Davies SJ, Shih CH, Noble M, Mayer-Proschel M, Davies JE, Proschel C. Transplantation of specific human astrocytes promotes functional recovery after spinal cord injury. PLOS ONE. 2011;. doi:10.1371/journal.pone.0017328.

47. Kim H, Zahir T, Tator CH, Shoichet MS. Effects of dibutyryl cyclic-AMP on survival and neuronal differentiation of neural stem/progenitor cells transplanted into spinal cord injured rats. PLoS ONE. 2011;. doi:10.1371/journal.pone.0021744.

48. Samantaray S, Sribnick EA, Das A, Knaryan VH, Matzelle DD, Yallapragada AV, Reiter RJ, Ray SK, Banik NL. Melatonin attenuates calpain upregulation, axonal damage and neuronal death in spinal cord injury in rats. J Pineal Res. 2008;2008(44): 348-57. 